\title{
Opportunistic illnesses in Brazilian children with AIDS: results from two national cohort studies, 1983-2007
}

\author{
Alberto N Ramos Jr', Luiza H Matida², Norman Hearst ${ }^{3}$ and Jorg Heukelbach ${ }^{1 *}$
}

\begin{abstract}
Background: HAART has significantly reduced AIDS-related morbidity in children. However, limited evidence is available from developing countries regarding patterns of opportunistic illnesses. We describe these events and their associated factors in children with AIDS in Brazil.
\end{abstract}

Methods: This study is based on two representative retrospective multi-center cohorts including a total 1,859 children with AIDS, infected via mother-to-child transmission (MTCT), between 1983-2002. Opportunistic illnesses were described and analyzed over time. The association of demographic, clinical and operational data with the occurrence of opportunistic diseases was assessed.

Results: In total, 1,218 (65.5\%) had at least one event of an opportunistic disease. Variables significantly associated with occurrence of these events included: region of residence (OR 2.68-11.33, as compared to the Northern region), age $<1$ year at diagnosis (OR 2.56,95\% Cl 1.81-3.61, $\mathrm{p}<0.001)$, and non-performance of MTCT prevention measures (OR 1.58, 95\% Cl 1.21-2.07, $\mathrm{p}<0.001$ ). Protective factors included year of HIV diagnosis in the HAART era (OR 0.34, $95 \% \mathrm{Cl} 0.15-0.76, \mathrm{p}=0.009)$ and ART use (OR 0.58, 95\% Cl 0.44-0.77, $\mathrm{p}<0.001)$. In both periods bacterial infections represented the most common opportunistic events (58.6 vs. 34.7\%; $\mathrm{p}<0.001$ ), followed by Pneumocystis jirovecii pneumonia (21.9 vs. 13.2\%; $p<0.001$ ), and bacterial meningitis/sepsis (16.8 vs. $7.4 \% ; p<0.001$ ).

Conclusions: Despite the significant reduction in recent years, opportunistic illnesses are still common in Brazilian children with AIDS in the HAART era, especially bacterial diseases. The data reinforce the need for scaling up prevention of MTCT, early diagnosis of infection, and improvement of comprehensive pediatric care.

\section{Background}

Over the past 15 years, both morbidity and mortality associated with human immunodeficiency virus (HIV) have been systematically reduced in children. Greater knowledge on the clinical course, early diagnosis of HIV infection, adoption of prophylaxis, improved management of opportunistic diseases, and introduction of antiretroviral therapy (ART) contributed to this trend [1-4]. New patterns of morbidity associated with chronic diseases have been described recently in HIV-infected individuals [5-7].

\footnotetext{
* Correspondence: heukelbach@web.de

'Department of Community Health, School of Medicine, Federal University of Ceará, Rua Professor Costa Mendes 1608, $5^{\circ}$ andar-Bloco Didático-Rodolfo Teófilo; CE-CEP: 60430-140, Fortaleza, Ceará, Brazil

Full list of author information is available at the end of the article
}

The adoption of highly active antiretroviral therapy (HAART) also has had an important role in modifying the natural history of HIV infection in children, characterized by a reduction of the progression to AIDS. The limited evidence available in children exposed to HIV via mother to child transmission (MTCT) shows reduced rates of clinical events in category "C" of CDC revised classification system for HIV infection. Early diagnosis of HIV infection and HAART has led to a reduction in the frequency of opportunistic diseases in children with subsequent reduced number of hospitalizations [4,8-10]. However, severe bacterial infections, mostly pneumonia, were still observed, even in children without severe immunosuppression [11].

Brazil stands out among the developing countries due to its sustained policy of HIV control, with a history of 25 years of a national control program [6]. Since 1996,

C Biomed Central

(C) 2011 Ramos et al; licensee BioMed Central Ltd. This is an Open Access article distributed under the terms of the Creative Commons Attribution License (http://creativecommons.org/licenses/by/2.0), which permits unrestricted use, distribution, and reproduction in any medium, provided the original work is properly cited. 
the country guarantees free and universal access to antiretroviral drugs $[6,12]$. Additionally, there is an established health service network for qualified management of HIV infection and opportunistic infections [13]. Since the beginning of the HAART era, significant impacts were observed in Brazil, including a significant reduction of MTCT, AIDS-related hospital admissions, morbidity and mortality. Since 1996, there was a downward trend in mortality in this population corresponding to a relative reduction of $63.6 \%$ in all children and $71.2 \%$ in children under 5 years of age [6]. However, few children, especially those from highly vulnerable families still acquire HIV from their mothers and may develop AIDS. Two national cohort studies have shown an increased survival of these children with AIDS [14-17]. The probability of survival 60 months after diagnosis, which was $53 \%$ among those diagnosed with AIDS between 1983 and 1998, increased to $88 \%$ between 1999 and 2002 [14].

Few studies have evaluated changes of clinical patterns with the introduction of HAART in children [18]. The aim of this study is to determine the global and specific frequencies of AIDS-defining illnesses and associated factors in the two national Brazilian cohorts of children with AIDS.

\section{Methods}

\section{Study Design and Population}

This study is based on analysis of two representative multicenter retrospective cohort studies on survival in Brazilian children with AIDS, infected by mother-to-child transmission (MTCT). Both studies followed similar methodological procedures, as described in detail previously [14-17]. Children with HIV/AIDS were defined as those under 13 years of age, based on the national AIDS case definitions in children [6]. In the first cohort, AIDS was defined by the 1994 Brazilian criteria (modified CDC definition and confirmation by signs) [19]; in the second, by the 2003 Brazilian criteria (modified CDC definition [clinical immunodeficiency], confirmation by signs, CD4 criterion [laboratorial immunodeficiency-lymphocyte count, by age strata], death exceptional criterion and death criterion) $[6,20]$.

The first study included 914 Brazilian children with AIDS diagnosed between January 1, 1983 and December 31,1998 . The status of children (dead or alive) was based on the follow-up until death or the end of 2002 $[15,17]$. The second study was composed of 945 children with AIDS diagnosed between January 1, 1999 and December 31, 2002, followed up until death or the end of 2007 [14,16].

\section{Data analysis}

We considered the first clinical event (primary episode) of each opportunistic illness associated with AIDS in any time of the children follow-up. Based on the Centers for Disease Control and Prevention (CDC) definition [21] and on the Brazilian guidelines [20], we included 20 severe opportunistic diseases indicative of AIDS (category " $C$ "-CDC revised classification system for HIV infection). The opportunistic diseases considered for analysis are depicted in the Table 1.

Clinical events were diagnosed by pediatricians with experience in management of HIV-1 infection, and data were registered in medical records. We reviewed retrospectively these medical records regarding the clinical events. To establish the diagnosis, we followed the Brazilian criteria for definition of AIDS cases in children, based on presumptive and/or definitive diagnosis [20]. We analyzed separately invasive bacterial infection, including or not bacterial meningitis or sepsis. The first group represents largely cases with severe pneumonia.

We verified the occurrence of these opportunistic diseases in the pre-HAART $(<1995)$ and HAART eras (1996-2007), using 1996 as a cut point. Odds ratios (OR) with their respective $95 \%$ confidence intervals (95\% CI) were calculated for quantitative comparison of relative frequencies. Additionally, we analyzed variables possibly associated with the occurrence of AIDS-defining diseases. Brazilian regions (child' residence), gender, birth cohort (< $1988,1989-1995$, and 1996-2002), age group $(<1,1-5$, and 6-12 years of age in HIV diagnosis), ART use (in any time), year of ART initiation (<1996, and 1996-2002), vital status (alive or dead), prenatal care, breast-feeding, and MTCT prophylaxis. Chi-squared and Fisher's exact tests were used where applicable. Statistical analysis was done with the STATA 11.0 software package (Stata Corporation, College Station, USA).

\section{Ethical considerations}

Both studies were approved by the Ethical Review Board of the Center for Reference and Training in STD/AIDS of São Paulo State, following the guidelines of the National Health Council.

\section{Results}

Epidemiological and demographic characteristics of children included in the analysis are detailed in Table 2. Among these 1,859 children, about half resided in Brazil's Southeast region. The majority was aged 1-5 years at diagnosis, with more than two thirds still alive at the end of follow-up. In total, 1,321 (75.2\%) of cases were diagnosed at an advanced staged as defined by category "C". Most cases had their AIDS diagnosis established between 1996-2002 and at some point used ART for HIV infection treatment during follow-up, mainly during 1996-2002. A high proportion of mothers had received prenatal care and breast-fed; MTCT preventive measures were not used in the majority of cases (Table 2). 
Table 1 Listing and characteristics of selected AIDS-defining illness in children from the two Brazilian cohorts

\begin{tabular}{|c|c|}
\hline AIDS-Defining Illness & Characteristics \\
\hline AIDS Wasting syndrome & HIV-related \\
\hline $\begin{array}{l}\text { Bacterial infections (excluding } \\
\text { meningitis or sepsis) }\end{array}$ & $\begin{array}{l}\text { Severe, multiple or recurrent (at least } 2 \text { confirmed episodes, 2-year): pneumonia, bone/joint infection, abscess } \\
\text { of internal organs, excluding otitis media, abscesses of skin and mucous membranes and catheter-related } \\
\text { infections }\end{array}$ \\
\hline Bacterial meningitis or sepsis & Severe, multiple or recurrent (at least 2 confirmed episodes, 2 -year) \\
\hline Candidiasis & Esophageal, trachea, bronchi or lungs \\
\hline Coccidioidomicosis & Disseminated \\
\hline Cryptococcosis & Extrapulmonary \\
\hline Cryptosporidiosis & Chronic intestinal, with diarrhea persisting for $>1$ month \\
\hline Cytomegalovirus disease & Onset of symptoms after 1 month of age, at a site other than liver, spleen or lymph nodes \\
\hline Disseminated mycobacterial disease & $\begin{array}{l}\text { Mycobacterium avium complex or disease caused by Mycobacterium kansasii, at a site other than lungs, skin } \\
\text { or cervical/hilar lymph nodes (except tuberculosis or Hansen's disease) }\end{array}$ \\
\hline Encephalopathy & HIV-related \\
\hline Herpes simplex virus & Chronic ulcer(s) in the bronchi, lungs or gastrointestinal tract \\
\hline Herpes simplex virus, mucocutaneous & Persisting for $>1$ month affecting children $>1$ month of age \\
\hline Disseminated histoplasmosis & At a site other than exclusively pulmonary or cervical/hilar lymph nodes \\
\hline Isosporiasis & Chronic intestinal, persisting for $>1$ month \\
\hline Kaposi's sarcoma & Human herpes virus 8-related \\
\hline Lymphoma & $\begin{array}{l}\text { Primary, in brain or lymphoma, non-Hodgkin B-cell lymphoma (unknown immunologic phenotype) and } \\
\text { other lymphomas: large or small, non-cleaved cells (Burkitt or non-Burkitt) or immunoblastic malignant } \\
\text { lymphoma no further specified }\end{array}$ \\
\hline Pneumocystis jirovecii pneumonia & Interstitial pneumonia \\
\hline $\begin{array}{l}\text { Progressive multifocal } \\
\text { leukoencephalopathy }\end{array}$ & JC virus-related \\
\hline Salmonella & Sepsis, recurrent (non-typhoid) \\
\hline Toxoplasmosis of brain & Encephalitis with onset after 1 month of age \\
\hline
\end{tabular}

About two thirds of children presented opportunistic infections during the observation period with a significantly lower occurrence of at least one of these events in the second cohort (OR 0.25, 95\% CI 0.20-0.30 p < $0.001)$. The bivariate analysis of factors associated with the occurrence of opportunistic infections is depicted in Table 2. The most important factors associated were: region of residence within in Brazil (OR 2.68-11.33, as compared to the Northern region), low age at diagnosis (OR 2.56), and performance of MTCT prevention measures (OR 1.58). The use of ART has a protective effect. Children of the second cohort study and those diagnosed after HAART availability also developed significantly less opportunistic illnesses. Gender, pre-natal care and breastfeeding were not significantly associated with the occurrence of opportunistic diseases (Table 2).

Among the 1,218 children with at least one opportunistic disease, in most cases this disease was defined by presumptive diagnosis: 651 children (88.2\%) in the first cohort, and $383(79.8 \%)$ in the second (OR 1.90, 1.39$2.59, \mathrm{p}<0.001)$. The occurrence of specific opportunistic illnesses is presented in Table 3. In both preHAART and HAART eras, bacterial infections (excluding meningitis and sepsis) were the most frequent events (58.6\% vs. $34.7 \%$ ), followed by $P$. jirovecii pneumonia
(21.9\% vs. $13.2 \%)$ and bacterial meningitis/sepsis $(16.8 \%$ vs. 7.4\%). We observed a decreased proportion of cases in the second cohort, as compared to the period $<1988$. Considering the pre-HAART and HAART eras, a significant decrease was also observed (OR 0.29, 0.23-0.37, $\mathrm{p}<0.001$ ) (Table 3).

The analysis related to HIV infection diagnosis in the pre-HAART and HAART eras shows a statistically significant reduction for invasive bacterial infection meningitis, $P$. jirovecii pneumonia, bacterial meningitis or sepsis, cryptosporidiosis, and cryptococcosis (Table 2). There were no reported cases of disseminated coccidioidomycosis and disseminated histoplasmosis in both periods, and no cases of progressive multifocal leukoencephalopathy in the HAART era (Table 3).

\section{Discussion}

This study represents the first population-based evidence regarding the occurrence and trends of opportunistic illnesses in Brazilian children with AIDS [12,16]. The second national cohort study showed a higher proportion of children exposed to HAART, as compared to the first study (65\% vs. 35\%). However, despite the significant reduction, opportunistic illnesses still were important for AIDS-related morbidity, with more than 
Table 2 Epidemiological and demographic characteristics of children, and bivariate analysis of factors associated with first event of opportunistic illnesses

\begin{tabular}{|c|c|c|c|c|c|}
\hline & & $\begin{array}{l}\text { Total } \\
\mathrm{N}(\%)\end{array}$ & $\begin{array}{c}\text { Opportunistic illness } \\
\mathrm{N}(\%)\end{array}$ & $\begin{array}{c}\text { OR } \\
(95 \% \mathrm{Cl}) \\
\end{array}$ & $p$ \\
\hline Total & - & $1859(100.0)$ & $1218(65.5 \%)$ & - & - \\
\hline \multirow[t]{2}{*}{ Study cohort } & 1983-1998 & $914(49.2)$ & $738(80.7)$ & ref & \\
\hline & 1999-2002 & $945(50.8)$ & $480(50.8)$ & $0.25(0.20-0.30)$ & $<0.001$ \\
\hline \multirow[t]{5}{*}{ Brazilian region (residence) } & North & $107(5.8)$ & $23(21.5)$ & ref & \\
\hline & Northeast & $288(15.5)$ & $122(42.4)$ & $2.68(1.62-4.46)$ & $<0.001$ \\
\hline & Southeast & $931(50.1)$ & $704(75.6)$ & $11.33(7.51-17.09)$ & $<0.001$ \\
\hline & South & $395(21.2)$ & $267(67.6)$ & $7.62(4.78-12.13)$ & $<0.001$ \\
\hline & Central-West & $138(87.4)$ & $102(73.9)$ & $10.35(5.89-18.18)$ & $<0.001$ \\
\hline \multirow[t]{2}{*}{ Gender } & Male & $909(48.9)$ & $594(65.3)$ & ref & \\
\hline & Female & $950(51.1)$ & $624(65.7)$ & $1.02(0.84-1.23)$ & 0.88 \\
\hline \multirow[t]{3}{*}{ Birth cohort } & $<1988$ & $155(8.3)$ & $127(81.9)$ & ref & \\
\hline & 1989-1995 & $819(44.1)$ & $582(71.1)$ & $0.54(0.35-0.83)$ & 0.006 \\
\hline & 1996-2002 & $885(47.6)$ & $509(57.5)$ & $0.30(0.20-0.45)$ & $<0.001$ \\
\hline \multirow[t]{3}{*}{ Age Group, HIV diagnosis } & $<1$ year & $667(35.9)$ & $515(77.2)$ & $2.56(1.81-3.61)$ & $<0.001$ \\
\hline & $1-5$ years & $1020(54.9)$ & $605(59.3)$ & $1.10(0.79-1.53)$ & 0.62 \\
\hline & $6-12$ years & $172(9.3)$ & $98(57.0)$ & ref & \\
\hline \multirow[t]{3}{*}{ Year, HIV diagnosis } & $<1988$ & $35(1.9)$ & $28(80.0)$ & ref & \\
\hline & 1989-1995 & $544(29.3)$ & $449(82.5)$ & $1.18(0.50-2.78)$ & 0.65 \\
\hline & 1996-2002 & $1280(68.9)$ & $741(57.9)$ & $0.34(0.15-0.76)$ & 0.009 \\
\hline \multirow[t]{2}{*}{ ART use } & Yes & 1555 (83.6) & $990(63.7)$ & $0.58(0.44-0.77)$ & $<0.001$ \\
\hline & No & $304(16.4)$ & $228(75.0)$ & ref & \\
\hline \multirow{2}{*}{ Year, ART initiation } & $<1996$ & $314(20.2)$ & $259(82.5)$ & ref & \\
\hline & 1996-2002 & $1241(79.8)$ & $731(58.9)$ & $0.30(0.23-0.41)$ & $<0.001$ \\
\hline \multirow[t]{2}{*}{ Children status } & Alive & $1226(68.9)$ & $695(56.7)$ & $0.26(0.20-0.33)$ & $<0.001$ \\
\hline & Dead & $554(31.1)$ & $463(83.6)$ & ref & \\
\hline \multirow[t]{2}{*}{ Prenatal care } & Yes & 818 (76.6) & $533(65.2)$ & $1.07(0.80-1.44)$ & 0.65 \\
\hline & No & $250(23.4)$ & $159(63.6)$ & ref & \\
\hline \multirow[t]{2}{*}{ Breast-feeding } & Yes & $969(78.7)$ & $628(64.8)$ & $0.92(0.69-1.22)$ & 0.56 \\
\hline & No & $262(21.3)$ & $175(66.8)$ & ref & \\
\hline \multirow[t]{2}{*}{ MTCT prophylaxis } & Yes & $254(15.3)$ & $139(54.7)$ & ref & \\
\hline & No & $1404(84.7)$ & $922(65.7)$ & $1.58(1.21-2.07)$ & 0.001 \\
\hline
\end{tabular}

half of the children with at least one event in the more recent cohort.

The impact of HAART on the reduction of progression to AIDS in children has been described repeatedly [2,3,5,8,10,22-24], even in developing countries [25-27]. However, few population-based studies have evaluated changes in the pattern of occurrence of diseases associated with HIV/AIDS $[11,18,28,29]$. Our data show a significant reduction in occurrence of all opportunistic illness in the HAART era: children that were born, or diagnosed with HIV/AIDS or had ART initiation after 1996 consistently and significantly reducing the chances of having opportunistic illness. However we identified a persisting relative importance of some specific events such as invasive bacterial diseases. A study conducted in Italy in a cohort of 1,402 children exposed to HIV through MTCT and representative of the pre-HAART
(1985-1995) and HAART (1996-2000 and 2001-2005) periods showed the progressive reduction in the rate of specific clinical events, similar to our study with persisting high rates of serious bacterial infections, particularly pneumonia [11]. In Brazil, a previous study conducted in Minas Gerais State (Southeast region) in a referral center showed that the effectiveness of HAART was associated with significant reduction in the incidence of opportunistic infections in 371 children observed between 1989 and 2003 [18]. However, these data were not representative for the AIDS population.

In contrast to these previous studies, we observed that about $1 / 7$ of children still presented $P$. jirovecii pneumonia in the HAART era reflecting the late diagnosis and management of HIV infection, despite the significant reduction in the incidence of this event. In our study cryptosporidiosis was significantly reduced (more than 
Table 3 Occurrence of first event of opportunistic illnesses in the two Brazilian national cohorts of children with AIDS ( $n=1,859)$

\begin{tabular}{|c|c|c|c|c|c|}
\hline \multirow[b]{2}{*}{ Opportunistic illness } & \multirow[b]{2}{*}{$\begin{array}{l}\text { Total } \\
\text { N (\%) }\end{array}$} & \multicolumn{2}{|c|}{ Cohort-HIV Diagnosis } & \multirow[b]{2}{*}{$\begin{array}{c}\text { OR } \\
(95 \% \mathrm{Cl})\end{array}$} & \multirow[b]{2}{*}{$\mathbf{P}$} \\
\hline & & $\begin{array}{c}\text { Pre-HAART Era } \\
\text { N (\%) }\end{array}$ & $\begin{array}{l}\text { HAART Era } \\
\mathrm{N}(\%)\end{array}$ & & \\
\hline Invasive bacterial infection (excluding meningitis and septicemia) & $791(42.6)$ & $359(58.6)$ & $432(34.7)$ & $2.66(2.19-3.24)$ & $<0.001$ \\
\hline P. jirovecii pneumonia & $298(16.0)$ & $134(21.9)$ & $164(13.2)$ & $1.85(1.44-2.37)$ & $<0.001$ \\
\hline Bacterial meningitis or sepsis & $195(10.5)$ & $103(16.8)$ & $92(7.4)$ & $2.53(1.89-3.39)$ & $<0.001$ \\
\hline Wasting syndrome & $179(9.6)$ & $91(10.0)$ & $88(9.3)$ & $1.09(0.80-1.48)$ & 0.637 \\
\hline HIV encephalopathy & $145(7.8)$ & $54(8.8)$ & $91(7.3)$ & $1.23(0.86-1.74)$ & 0.270 \\
\hline Cytomegalovirus infection & $106(5.7)$ & $40(6.5)$ & $66(5.3)$ & $1.25(0.83-1.87)$ & 0.289 \\
\hline Candidiasis & $101(5.4)$ & $35(5.7)$ & $66(5.3)$ & $1.08(0.71-1.65)$ & 0.744 \\
\hline Cryptosporidiosis & $50(2.7)$ & $36(5.9)$ & $14(1.1)$ & $5.49(3.13-9.62)$ & $<0.001$ \\
\hline Herpes simplex, gingivostomatitis & $39(2.1)$ & $20(2.2)$ & $19(2.0)$ & $1.09(0.58-2.06)$ & 0.872 \\
\hline Cerebral toxoplasmosis & $33(1.8)$ & $13(2.1)$ & $20(1.6)$ & $1.33(0.66-2.68)$ & 0.457 \\
\hline Herpes simplex, mucocutaneous & $25(1.3)$ & $10(1.6)$ & $15(1.2)$ & $1.36(0.61-3.04)$ & 0.521 \\
\hline Disseminated mycobacterial disease & $22(1.2)$ & $9(1.5)$ & $13(1.0)$ & $1.41(0.60-3.31)$ & 0.494 \\
\hline Isosporiasis & $21(1.1)$ & $11(1.2)$ & $10(1.1)$ & $1.14(0.48-2.69)$ & 0.829 \\
\hline Lymphoma & $17(0.9)$ & $7(1.1)$ & $10(0.8)$ & $1.43(0.54-3.75)$ & 0.450 \\
\hline Cryptococcosis & $15(0.8)$ & $10(1.6)$ & $5(0.4)$ & $4.12(1.52-11.14)$ & 0.010 \\
\hline Kaposi's sarcoma & $3(0.2)$ & $2(0.3)$ & $1(0.1)$ & $4.08(0.44-37.42)$ & 0.254 \\
\hline Leukoencephalopathy & $3(0.2)$ & $3(0.5)$ & $0(0.0)$ & - & - \\
\hline Salmonellosis & $2(0.1)$ & $1(0.2)$ & $1(0.1)$ & $2.03(0.13-30.79)$ & 0.551 \\
\hline Histoplasmosis & $0(0.0)$ & $0(0.0)$ & $0(0.0)$ & - & - \\
\hline Coccidioidomycosis & $0(0.0)$ & $0(0.0)$ & $0(0.0)$ & - & - \\
\hline
\end{tabular}

five times), as observed in other studies [11,29]. For other diseases (excluding cryptococcosis), despite the indication of reduction in the proportion of cases in the second period, there was not a significant difference between the periods.

Children with AIDS diagnosed between 1996-2002 had a three times lower odds of having opportunistic infections, as compared to those born before the release of any ARV. Thus, they had the chance to be treated with ARV, even in advanced stages of HIV infection $[6,13,14]$.

Operational issues related to health services examined in this study, as the realization of prenatal care and adoption of breastfeeding were not significantly associated with the occurrence of opportunistic events, the first guidelines for management of HIV infection and opportunistic diseases were published in 1994, and the first therapeutic consensus was established in 1996. Expanded further actions for the prevention of MTCT have occurred since 1999 [6]. Despite these advances in national policy for control of HIV [13,30], there are indications of operational failures in these procedures [30-32]. Additionally, regional differences are important factors that contribute in Brazil to sustain a non-favorable outcome $[16,17,30]$. Our study points to a statistically significant association between non-performance of any measure aimed at the prevention of MTCT (prenatal or childbirth or child) and the occurrence of these clinical events. Approximately one seventh of the children had undergone some of the interventions to prevent MTCT, but still acquired HIV and developed AIDS. Probably, ongoing care and routine monitoring of children exposed to HIV would have prevented opportunistic illnesses in these cases. The vast majority of children in this study was born after 1995 (and about half of them after 1997), after wide implementation of MTCT control measures, evidencing a missed opportunity to prevent HIV transmission and to start HAART early.

We identified a positive association between the occurrences of opportunistic illnesses in all regions of the country compared with the North region, mainly in the Southeast where the epidemic is consolidated since the very beginning [30]. It is noteworthy that the North region had the lowest proportion of AIDS cases in the two periods $(2 \%$ vs. $9 \%)$. After the period analyzed in these two cohorts, the North had a progressive increasing of incidence and mortality rates related to AIDS, which may have led to changes in the relative occurrence of these events when comparing regions $[13,33]$.

Children aged $<1$ year of age had a higher frequency of opportunistic illness compared with children aged 1-5 and 6-12 years. This population of children is known to progress more rapidly to AIDS, with strong evidence of efficacy of early treatment $[4,8,34]$, which indicates the need for earlier interventions for the treatment of HIV 
infection. Based on this evidence, since 2009 Brazil has adopted measures on their therapeutic guidelines recommending the treatment of all HIV infected children $<1$ year of age regardless of clinical symptoms, immunological classification or HIV viral load [35].

This study is based on the two unique national cohorts of children with AIDS for survival analysis with a representative number of children with AIDS in the country and its regions. Considering the sheer magnitude of the analyzed period (1983-2007), measures adopted for data collection were standardized, with a systematic review of all data collected, and minimizing the effects related to changes in criteria for AIDS cases definition, management/diagnosis of opportunistic infections and ART.

The present study has limitations beyond those already identified and described extensively in our previous publications on the topic [14-17]. Children in both cohorts had differing criteria for AIDS case definition, with greater sensitivity in the last one [6]. This may underestimate the occurrence of opportunistic diseases in this cohort. The presumptive diagnosis in health services may be related to difficulties of clinical diagnosis in some cases, the nature of each specific disease, technical conditions, such as provision of technical conditions for complementary diagnosis and experience of medical professionals with HIV/AIDS in children. Moreover, issues such as underreporting of clinical events and drop-out of some children during the periods specified in the two survival studies may have biased our results.

Considering the study period (1983-2007) and the advance of the Brazilian policy for the control and management of HIV infection/AIDS even after the introduction of HAART, the period after 2002 may have possibly a different pattern of occurrence of opportunistic conditions, indicating the need for further studies.

\section{Conclusions}

The present study provides evidence for the reduction of morbidity related to AIDS-defining opportunistic illnesses in Brazilian children exposed to HIV through MTCT. This result reflects a period of further consolidation of HAART in a developing country with extensive commitment of the public sector to providing treatment. Bacterial diseases remain the most important opportunistic disease. Our study emphasizes the need to continually expand efforts to prevent MTCT of HIV, early diagnosis of infection, and improved care of pediatric AIDS patients.

\section{Acknowledgements and funding}

The authors thank: the Brazilian Study Group on Survival of Children with AIDS technical coordinating team included Alberto Novaes Ramos Jr., Heloisa H. S. Marques, Jörg Heukelbach, Luiza H. Matida (Coordinator),
Marinella D. Negra, Norman Hearst, and Regina C. M. Succi. This work was carried out by the Fundação São Vicente (Fundasv) with technical and financial support of the Ministry of Health/Secretariat of Health Surveillance/ Department of STD, Aids and Viral Hepatitis through the Project of International Technical Cooperation AD/BRA/03/H34 between the Brazilian Government and the United Nations Office on Drugs and Crime-UNODC. JH is research fellow from the National Council for Scientific and Technological Development (CNPq), an agency linked to the Ministry of Science and Technology (MCT), Brazil.

\section{Author details}

${ }^{1}$ Department of Community Health, School of Medicine, Federal University of Ceará, Rua Professor Costa Mendes 1608, $5^{\circ}$ andar-Bloco Didático-Rodolfo Teófilo; CE-CEP: 60430-140, Fortaleza, Ceará, Brazil. ²STD/AIDS State Program, São Paulo, Brazil. ${ }^{3}$ Department of Family and Community Medicine, University of California, San Francisco, USA

\section{Authors' contributions}

ANRJ participated in the study concept and design, had full access to all of the data, carried out acquisition, analysis, and interpretation of the data, drafted the manuscript. LHM participated in the study conception and design, and acquisition of data; had full access to all of the data, carried interpretation of the data, revising critically the manuscript. $\mathrm{NH}$ carried out interpretation of the data, revising critically the manuscript. $\mathrm{JH}$ participated in the study concept and design, had full access to all of the data, carried out analysis, and interpretation of the data, drafted the manuscript. All authors read and approved the final manuscript.

\section{Competing interests}

The authors declare that they have no competing interests.

Received: 3 March 2011 Accepted: 18 July 2011 Published: 18 July 2011

\section{References}

1. Brady MT, Oleske JM, Williams PL, Elgie C, Mofenson LM, Dankner WM, Van Dyke RB: Declines in mortality rates and changes in causes of death in HIV-1-infected children during the HAART era. J Acquir Immune Defic Syndr 2010, 53:86-94.

2. Judd A, Doerholt K, Tookey PA, Sharland M, Riordan A, Menson E, Novelli V, Lyall EG, Masters J, Tudor-Williams G, Duong T, Gibb DM, Collaborative HIV Paediatric Study (CHIPS), National Study of HIV in Pregnancy and Childhood (NSHPC): Morbidity, mortality, and response to treatment by children in the United Kingdom and Ireland with perinatally acquired HIV infection during 1996-2006: planning for teenage and adult care. Clin Infect Dis 2007, 45:918-924.

3. Palladino C, Bellon JM, Jarrin I, Gurbindo MD, De Jose Ml, Ramos JT, Gonzalez-lome MI, Mellado MJ, Beceiro J, Del Amo J, Munoz-Fernandez MA: Impact of highly active antiretroviral therapy (HAART) on AIDS and death in a cohort of vertically HIV type 1-infected children: 1980-2006. AIDS Res Hum Retroviruses 2009, 25:1091-1097.

4. Violari A, Cotton MF, Gibb DM, Babiker AG, Steyn J, Madhi SA, JeanPhilippe P, Mclntyre JA: Early antiretroviral therapy and mortality among HIV-infected infants. N Engl J Med 2008, 359:2233-2244.

5. Hazra R, Siberry GK, Mofenson LM: Growing up with HIV: children, adolescents, and young adults with perinatally acquired HIV infection. Annu Rev Med 2010, 61:169-185.

6. Ramos AN Jr, Matida L, Hearst N, Heukelbach J: AIDS in Brazilian Children: History, Surveillance, Antiretroviral Therapy and Epidemiological Transition, 1984-2008. Aids Pat Care STD 2011, 25:245-255.

7. Pacheco AG, Tuboi SH, Faulhaber JC, Harrison LH, Schechter M: Increase in non-AIDS related conditions as causes of death among HIV-infected individuals in the HAART era in Brazil. PLoS One 2008, 3:e1531.

8. Goetghebuer T, Haelterman E, Le Chenadec J, Dollfus C, Gibb D, Judd A, Green H, Galli L, Ramos JT, Giaquinto C, Warszawski J, Levy J, for the European Infant Collaboration group: Effect of early antiretroviral therapy on the risk of AIDS/death in HIV-infected infants. AIDS 2009, 23:597-604.

9. Vandermaelen A, Barlow P, Manigart Y, Hainaut M, Goetghebuer T, Levy J, Gerard M, Rozenberg S: Optimal management of HIV-infected women during pregnancy and delivery: an audit of compliance with recommendations. J Womens Health (Larchmt) 2009, 18:1881-1887. 
10. Zanchetta M, Anselmi A, Vendrame D, Rampon O, Giaquinto C, Mazza A Accapezzato D, Barnaba V, De Rossi A: Early therapy in HIV-1-infected children: effect on HIV-1 dynamics and HIV-1-specific immune response. Antivir Ther 2008, 13:47-55.

11. Chiappini E, Galli L, Tovo PA, Gabiano C, Lisi C, Gattinara GC, Esposito S, Vigano A, Giaquinto C, Rosso R, Guarino A, de Martino M: Changing patterns of clinical events in perinatally HIV-1-infected children during the era of HAART. AIDS 2007, 21:1607-1615.

12. Nunn AS, da Fonseca EM, Bastos FI, Gruskin S: AIDS treatment in Brazil: impacts and challenges. Health Aff (Millwood) 2009, 28:1103-1113.

13. Brazilian Ministry of Health: Brazilian Targets and Commitments made by MemberStates at the United Nations General Assembly Special Session on HIV/AIDS UNGASS-HIV/AIDS: Brazilian Response 2008-2009 Country Progress Report, March 2010. Brasília: BMoH; 2010, 1-150 [http://www. unaids.org/en/dataanalysis/monitoringcountryprogress/ 2010progressreportssubmittedbycountries/ brazil_2010_country_progress_report_en.pdf].

14. Matida LH, Ramos AN Jr, Heukelbach J, Sanudo A, Succi RCM, Marques HHS, Negra MD, Hearst N: Improving survival in children with AIDS in Brazil: results of the second national study, 1999-2002. Cad Saude Publica 2011, 27(Suppl 3):S93-103.

15. Matida LH, Marcopito LF, Succi RC, Marques HH, Della Negra M, Grangeiro A, Hearst N: Improving survival among Brazilian children with perinatally-acquired AIDS. Braz J Infect Dis 2004, 8:419-423.

16. Matida LH, Ramos AN Jr, Heukelbach J, Hearst N: Continuing improvement in survival for children with acquired immunodeficiency syndrome in Brazil. Pediatr Infect Dis J 2009, 28:920-922.

17. Matida LH, Ramos AN Jr, Moncau JE, Marcopito LF, Marques HH, Succi RC, Della Negra M, Hearst N: AIDS by mother-to-child transmission: survival analysis of cases followed from 1983 to 2002 in different regions of Brazil. Cad Saude Publica 2007, 23(Suppl 3):S435-444.

18. Candiani TM, Pinto J, Cardoso CA, Carvalho IR, Dias AC, Carneiro M, Goulart EA: Impact of highly active antiretroviral therapy (HAART) on the incidence of opportunistic infections, hospitalizations and mortality among children and adolescents living with HIV/AIDS in Belo Horizonte, Minas Gerais State, Brazil. Cad Saude Publica 2007, 23(Suppl 3):S414-423.

19. Brazilian Ministry of Health: Revisão da definição nacional de caso de AIDS em crianças, Brasil. Brasília: BMoH; 1994, 1-12.

20. Brazilian Ministry of Health: Critérios de definição de casos de aids em adultos e crianças, Brasil, 2003. Brasília: BMoH; 2004, 1-56 [http://www.aids. gov.br/sites/default/files/criterios_aids_2004.pdf].

21. Centers for Disease Control and Prevention: 1994 Revised Classification System for Human Immunodeficiency Virus Infection in Children Less Than 13 Years of Age. MMWR 1994, 43(RR-12):1-10.

22. Weinberg A, Dickover R, Britto P, Hu C, Patterson-Bartlett J, Kraimer J, Gutzman H, Shearer WT, Rathore M, McKinney R: Continuous improvement in the immune system of HIV-infected children on prolonged antiretroviral therapy. AIDS 2008, 22:2267-2277.

23. Patel K, Ming X, Williams PL, Robertson KR, Oleske JM, Seage GR: Impact of HAART and CNS-penetrating antiretroviral regimens on HIV encephalopathy among perinatally infected children and adolescents. AIDS 2009, 23:1893-1901.

24. Patel K, Hernan MA, Williams PL, Seeger JD, McIntosh K, Van Dyke RB, Seage GR: Long-term effectiveness of highly active antiretroviral therapy on the survival of children and adolescents with HIV infection: a 10-year follow-up study. Clin Infect Dis 2008, 46:507-515.

25. Ciaranello AL, Chang Y, Margulis AV, Bernstein A, Bassett IV, Losina E, Walensky RP: Effectiveness of pediatric antiretroviral therapy in resourcelimited settings: a systematic review and meta-analysis. Clin Infect Dis 2009, 49:1915-1927.

26. Janssens B, Raleigh B, Soeung S, Akao K, Te V, Gupta J, Vun MC, Ford N, Nouhin J, Nerrienet E: Effectiveness of highly active antiretroviral therapy in HIV-positive children: evaluation at 12 months in a routine program in Cambodia. Pediatrics 2007, 120:e1134-1140.

27. Sutcliffe CG, van Dijk JH, Bolton C, Persaud D, Moss WJ: Effectiveness of antiretroviral therapy among HIV-infected children in sub-Saharan Africa. Lancet Infect Dis 2008, 8:477-489.

28. Gray L, Newell ML, Thorne C, Peckham C, Levy J: Fluctuations in symptoms in human immunodeficiency virus-infected children: the first 10 years of life. Pediatrics 2001, 108:116-122.
29. Gona P, Van Dyke RB, Williams PL, Dankner WM, Chernoff MC, Nachman SA, Seage GR: Incidence of opportunistic and other infections in HIV-infected children in the HAART era. JAMA 2006, 296:292-300.

30. Ramos AN Jr, Matida LH, Saraceni V, Veras MA, Pontes RJ: Control of mother-to-child transmission of infectious diseases in Brazil: progress in HIV/AIDS and failure in congenital syphilis. Cad Saude Publica 2007, 23(Suppl 3):S370-378.

31. Veloso VG, Portela MC, Vasconcellos MT, Matzenbacher LA, Vasconcelos AL, Grinsztejn B, Bastos Fl: HIV testing among pregnant women in Brazil: rates and predictors. Rev Saude Publica 2008, 42:859-867.

32. Barcellos C, Acosta LM, Lisboa E, Bastos Fl: Surveillance of mother-to-child HIV transmission: socioeconomic and health care coverage indicators. Rev Saude Publica 2009, 43:1006-1014.

33. Brazilian Ministry of Health: Boletim Epidemiológico AIDS-DST, Ano VI $n^{\circ}$ 01-27 a $52^{\text {a }}$ semanas epidemiológicas-julho a dezembro de 2008-01 a a $26^{a}$ semanas epidemiológicas-janeiro a junho de 2009. Brasília: $\mathrm{BMoH}$; 2009, 1-67 [http://www.aids.gov.br/publicacao/boletim-epidemiologico2010].

34. Diaz C, Hanson C, Cooper ER, Read JS, Watson J, Mendez HA, Pitt J, Rich K, Smeriglio V, Lew JF: Disease progression in a cohort of infants with vertically acquired HIV infection observed from birth: the Women and Infants Transmission Study (WITS). J Acquir Immune Defic Syndr Hum Retrovirol 1998, 18:221-228.

35. Brazilian Ministry of Health: Recomendações para Terapia Antirretroviral em Crianças e Adolescentes Infectados pelo HIV: manual de bolso 2009, Série Manuais, n. 85. Brasilia: BMoH; 2009, 1-213 [http://www.aids.gov.br/ sites/default/files/consenso_pediatrico.pdf].

doi:10.1186/1742-6405-8-23

Cite this article as: Ramos et al: Opportunistic illnesses in Brazilian children with AIDS: results from two national cohort studies, 1983-2007. AIDS Research and Therapy 2011 8:23.

\section{Submit your next manuscript to BioMed Central and take full advantage of:}

- Convenient online submission

- Thorough peer review

- No space constraints or color figure charges

- Immediate publication on acceptance

- Inclusion in PubMed, CAS, Scopus and Google Scholar

- Research which is freely available for redistribution

Submit your manuscript at www.biomedcentral.com/submit
C) Biomed Central 